\title{
Prevalence of Infection with Hantavirus in Rodent Populations of Central Argentina
}

\author{
Olga V Suárez ${ }^{+}$, Gerardo R Cueto, Regino Cavia, Isabel E Gómez Villafañe/*, \\ David N Bilenca/*, Alexis Edelstein**, Paula Martínez**, Sergio Miguel**, \\ Carla Bellomo**, Karina Hodara, Paula J Padula*/**, María Busch/*
}

Laboratorio de Ecología de Poblaciones, Departamento de Ecología, Genética y Evolución, Universidad de Buenos Aires, Facultad de Ciencias Exactas y Naturales, Ciudad Universitaria, Pabellón II, $4^{\circ}$ piso, (C1428EHA), Buenos Aires, Argentina *Consejo

Nacional de Investigaciones Científicas y Tecnológicas Buenos Aires, Argentina **Instituto Nacional de Enfermedades Infecciosas, Anlis, Malbrán, Argentina

\begin{abstract}
We studied hantavirus seroprevalence and virus variability in rodent populations in Diego Gaynor, northwest of Buenos Aires province, Argentina. Rodent samplings were conducted in railroads and cropfield borders in March and July 1999, September and December 2000, and March 2001. Antibody detection was performed by an enzyme link immunosorbent assay (ELISA), using the recombinant nucleoprotein of Andes (AND) virus as antigen. Tissue samples were taken from positive antibody individuals in order to confirm the presence of hantavirus genomic material and to identify virus genotypes. Akodon azarae was the most abundant species, followed by Oligoryzomys flavescens, while Calomys laucha and $\mathrm{C}$. musculinus were rarely caught. We found a rate of seroprevalence of $9.3 \%$ for a total sample of $291 \mathrm{~A}$. azarae and 13.5\% for $37 \mathrm{O}$. flavescens. After molecular analyses of hantavirus, we confirmed the presence of hantavirus genomic material in 16 individuals with ELISA (+) results and two individuals with ELISA (-). Four amplimers for each species were sequenced and compared to the corresponding sequences of representative hantaviruses. We identified the AND Cent Lec from three $\mathrm{O}$. flavescens, and the Pergamino virus from four A. azarae and from one $\mathrm{O}$. flavescens. A. azarae males had higher seroprevalence than females, and heavier individuals showed higher seroprevalence than lighter ones. We did not find seroprevalence differences according to sex in $\mathrm{O}$. flavescens, although this result may have been produced by the low sample size. The lowest seroprevalence was found in a period of high rodent density, when juveniles prevailed in the population. We found higher seroprevalences than those detected in previous studies for other localities of central Argentina where cases of hantavirus pulmonary syndrome (HPS) have been reported. The presence of AND Cent Lec virus in rodent populations of the study area, which is responsible of HPS cases in central Argentina, suggests that human populations are at risk of HPS disease, although there were not reported cases of this disease until today.
\end{abstract}

Key words: sigmodontine rodents - hantavirus pulmonary syndrome - seroprevalence - Argentina

Hantavirus pulmonary syndrome (HPS) is a severe and often fatal cardiopulmonary disease that affects many people in America. After the outbreak of HPS in 1993 in Southwestern United States (Nichol et al. 1993), there was an increase in reports from cases in South America. Between 1993-2001, there have been 310 confirmed cases of HPS in Argentina, 91 in Paraguay, 204 in Chile, 167 in Brazil, 27 in Uruguay and 11 in Bolivia (PAHO 2002).

Rodent species of the subfamily Sigmodontinae are the main reservoirs of different types of hantaviruses throughout the continent. Calomys laucha was identified as the reservoir of the virus Laguna Negra, the etiologic agent of HPS in Paraguay (Yahnke et al. 2001), while three species of Oligoryzomys have been related to hantavirus transmission: O. longicaudatus (in Chile and Southern

Sources of financial support: Universidad de Buenos Aires (grant UBACYT TX 58), Consejo Nacional de Investigaciones Cientificas y Tecnológicas, Argentina (grant PIP 548/98), and Fundación "Alberto J. Roemmers" (Argentina)

${ }^{+}$Corresponding author. Fax: +54-11-4576.3384. E-mail: osuarez@bg.fcen.uba.ar

Received 4 December 2002

Accepted 10 July 2003
Argentina), O. chacoensis (in Northern Argentina, Padula et al. 2002), and O. flavescens in Central Argentina and Uruguay (Levis et al. 1998, González della Valle et al. 2002).

Serosurveys of wild rodents conducted in areas of Brazil where cases of HPS occurred found that Bolomys lasiurus and Oligoryzomys spp. may be potential reservoirs of hantaviruses in this country (Romano-Lieber et al. 2001). On the other hand, another study conducted in Brazil found a a seroprevalence of $28.8 \%$ in Holochilus sciureus (Vasconcelos et al. 2001).

In Argentina, the first cases of HPS were recorded and characterized in 1995 in the Southwest (López et al. 1996). Nowadays, the occurrence of cases is concentrated in three geographically isolated areas: North (Salta and Jujuy provinces), Center (Buenos Aires, Santa Fe and Entre Ríos provinces), and Southwest (Neuquén and Río Negro provinces). In an extensive study conducted in sites were HPS cases occurred, many sigmodontine species were found infected with hantavirus, with seroprevalences which varied between 1.5 and $10.2 \%$, depending on the area and species (Calderón et al. 1999, Cantoni et al. 2001, Sosa Estani et al. 2002, Gonzalez della Valle et al. 2002). López et al. $(1996,1997)$ described the virus associated to HPS cases in Argentina, Andes virus (AND), as a new type of hantavirus. This virus circulates in Argentina, Chile and Uruguay with different lineages that are 
characteristics of the different areas (Padula et al. 2000a). Although three species of the genus Oligoryzomys were identified as associated to hantavirus that caused HPS in Argentina, the reservoirs of two lineages of virus which caused HPS in Buenos Aires (AND Cent Buenos Aires and AND Cent Plata; Martínez et al. 2001) have not been identified yet. Moreover, there are two other types of virus, which have not been associated to human disease, until now, were identified from other sigmodontine species inhabiting the Buenos Aires province: Maciel virus (in Necromys obscurus), and Pergamino (in Akodon azarae) (Levis et al. 1998).

Previous studies of rodent hantavirus reservoirs in US (Abbott et al. 1999, Mills et al. 1999) and Argentina (Cantoni et al. 2001) suggest that the prevalence of infection is higher for adult males than for females and juveniles. Differences among demographic groups have been related to behavioral factors as agonistic interactions, to home range size, and to the age effect that increase the probability of being infected, suggesting that horizontal transmission is the main mechanism of maintaining the virus in nature (Abbott et al. 1999, Mills et al. 1999). Although seroprevalence variations according to changes in population density and structure have been described (Graham \& Chomel 1997, Kuenzi et al. 1999, Mills et al. 1999, Biggs et al. 2000, Cantoni et al. 2001), there is still not a clear pattern of variation of seroprevalence with density. When higher density is accompanied with an increase in the proportion of juveniles in the population, a lower seroprevalence have been related to a dilution effect (Mills et al. 1999).

This work shows results of a study conducted in order to study the prevalence of infection with different types of hantavirus in rodent populations of northwest Buenos Aires province, Argentina, and its variation according to species and demographic sub classes.

\section{MATERIALS AND METHODS}

Study area - Fieldwork was conducted at Diego Gaynor ( $\left.34^{\circ} 8^{\prime} \mathrm{S}, 59^{\circ} 14^{\prime} \mathrm{W}\right)$, Buenos Aires Province, Argentina (Fig. 1). The small rodent community in this area is composed by the sigmodontines $A$. azarae, C. laucha, $C$. musculinus, O.flavescens, Oxymycterus rufus, the cavid Cavia aperea and the murines Rattus norvegicus, R. rattus and Mus musculus.

Rodent populations show an annual cycle of population density in the study area, with a minimum in spring and a peak in late autumn-winter. The reproductive period lasts between September-October (spring) to autumn (March-April). The population structure changes along the seasons: in spring there is a great proportion of over- wintering adults, along the reproductive period are recruited juveniles and in autumn the population is composed by many age classes. Populations turnover annually, and the ecological longevity is $\leq 6$ months (Zuleta et al. 1988).

The original vegetation consisted of matted grasses 1 $\mathrm{m}$ high and trees were absent. Nowadays, the native vegetation is replaced by areas intensely cultivated (the most common crops are wheat, maize, sunflower and soybean), natural pastures, poultry farms and fields with cattle. Most of the remaining native plants are restricted to linear and less disturbed habitats including cropfield edges (borders), fence rows, roadsides and railroads (Mills et al. 1991, Busch \& Kravetz 1992).

Buenos Aires province is subdivided in political subunits, called partidos or departments, which have local political and sanitary authorities. Up to now, there were not reported human cases of HPS in the department of Exaltación de la Cruz (to which the study area belongs), but there were cases in the neighboring departments of Zárate, Campana and Pilar (Fig.1).

Rodent sampling and virologic analyses - Trapping was conducted in cropfield borders and railroads. We conducted five rodent samplings between March 1999 and March 2001 (Table). In March and July 1999 we conducted only removal samplings, while in the other dates we performed both capture-mark-recapture and removal samplings. The total trapping effort was of 750 trap-nights in each sampling. We used Sherman live traps which were active for three consecutive nights. The distance between neighbor traps was $10 \mathrm{~m}$. Captured

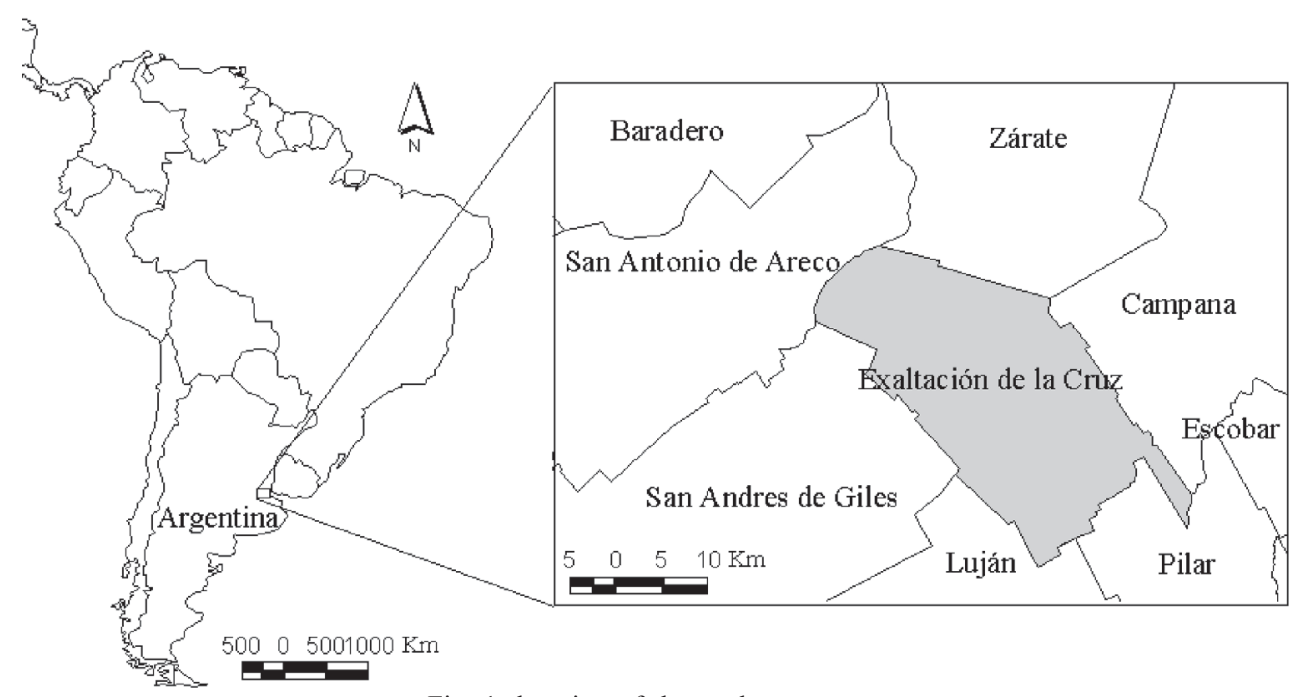

Fig. 1: location of the study area 
animals were collected each morning and carried to a centrally located field processing station. Animals were anesthetized with chloroform or ether. For each animal captured we recorded the species (according to external morphology), date and localization of capture, corporal length, weight, sex and reproductive condition. Reproductively active females (pregnant, with evidence of lactation or with open vaginas), and active males (with scrotal testes) were distinguished from reproductively inactive (females with closed vaginas and males with abdominal testes). We examined each animal for wounds (ear nicks, torn ears, scarred tails), and for evidences of infection by botfly larvae (Cuterebra, Diptera, Insecta), which may enhance the probability of infection (Mills \& Childs 1998).

Blood samples were collected from retroorbital sinus using heparinized capillary tubes, following Mills et al. (1995) or from the tail of all individuals captured, and an enzyme-linked immunosorbent assay (ELISA) was performed, with the recombinant nucleoprotein of the virus AND as antigen, for detection of specific IgG antibodies in serum or whole-blood (Padula et al. 2000b). Rodents from capture-mark-recapture areas were released at the site of capture after given an individual mark. Rodents captured in removal areas which were positive in the ELISA test were euthanized for taking organ tissue samples from lung and kidney, following Mills et al. (1995). We conducted molecular analyses in order to confirm the presence of genomic hantavirus material for 18 seropositive animals from which we had organ samples, and from two negative $O$. flavescens which were found dead in traps. Total RNA was extracted from lung or kidney tissues using the guanidine isothiocyanate-acid phenol extraction procedure as described in Padula et al. (2000b). We used the RNAid kit (Bio 101) for RNA purification. Partial S and M segments were amplified by RT-PCR followed by a second round of nested or heminested PCR. We used specific oligonucleotide primers based on conserved regions of AND virus genome. Amplifications were conducted from nucleotides 69 to 324 from the nucleoprotein coding region of the S segment and from nucleotides 2716 to 2943 from the M segment. Positions of the $\mathrm{S}$ and $\mathrm{M}$ segment fragments were numbered relative to AND virus. The amplification products were purified and sequenced by an ABI 377 sequencer by the fluorescent technique (d Rhodamine Terminator Cycle Sequencing kit Applied Biosystem). The analysis and comparison of the nucleotide and aminoacid sequences was made by the CLUSTAL program, included in PC/GENE 6.8, Intelligenetics Inc., Mountain View, CA.

Data analysis - Rodent density was estimated as the number of different individuals captured in each 3 day trapping period. Seroprevalence was estimated as the number of rodents which were positive in the ELISA test divided by the number of different rodents captured and tested.

We compared the proportions of seropositive individuals according to sampling period, species, sex and reproductive condition by means of a Chi-square analysis when sampling sizes were sufficient to statistical comparisons. For $O$. flavescens we compared the sex ratio of infected animals by means of a binomial test, considering that the proportion of each sex in the infected sample must be equal to the proportion in the total sample. We separated A. azarae individuals into weight classes I: $\leq 20 \mathrm{~g}$ (juveniles and subadults), II: $21-30 \mathrm{~g}$ (young adults), III $>30 \mathrm{~g}$ (old adults). For those animals which were recaptured we considered their serocondition (positive or negative) only at the moment of first capture.

\section{RESULTS}

We captured a total of 335 rodents, six of them were recaptured once, totalizing a total of 341 blood samples. A. azarae was the most common species $(86.9 \%$ of total individuals captured), followed by $O$. flavescens $(11 \%)$. C. laucha and C. musculinus were rarely captured (2.1\%). Only $4(1.4 \%, \mathrm{n}=291) \mathrm{A}$. azarae had wounds and $12(4.1 \%$, $\mathrm{n}=291$ ) were infected with cuterebrids. We did not detect wounds or cuterebrids in any O. flavescens $(\mathrm{n}=37)$.

Rodent abundance and population structure in the different sampling periods - The abundance of $A$. azarae varied between the two years studied, with a minimum in March 1999 and a maximum in March 2001 (Table). The pattern of variation among months within each year agreed with that observed for this species in other works, with increasing density from spring to autumn-winter (Zuleta et al. 1988).

In March 1999 the population was mainly formed by individuals of weight class III, while there was a low proportion of juveniles (class I). In July 1999 we found a higher proportion of class I, while there were few individuals of class III. In December 2000, there was a great proportion of the population in the first weight class, but all weight classes were represented. In March 2001 classes I and II were dominant in the population, while there were few individuals of class III (Fig. 2).

$O$. flavescens was less abundant than A. azarae, and it was more abundant in 1999 than in 2000-2001 (Table).

Antibody prevalence by species, sex and reproductive condition - AND virus antibody-reactive rodents were detected in the two most common captured species. Hantavirus seroprevalence was of $13.5 \%$ for a total sample of 37 O. flavescens and $9.3 \%$ for 291 A. azarae.

We did not find differences in seroprevalence between male and female $O$. flavescens $(10 \%, \mathrm{n}=20$, and $17.7 \%, \mathrm{n}$ $=17$, respectively, $\mathrm{P}=0.28$, binomial test).

A. azarae males were more frequently infected than females $(15.3 \%, \mathrm{n}=157$ and $2.3 \%, \mathrm{n}=133$ for males and females, respectively; $\chi^{2}=14,48 ; \mathrm{df}=1, \mathrm{P}<0.001$ ). Seroprevalence was higher for reproductively active $A$. azarae males $(21.1 \%, \mathrm{n}=76)$ than for inactive ones $(9.9 \%$, $\left.\mathrm{n}=81, \chi^{2}=3,78, \mathrm{df}=1, \mathrm{P}=0.05\right)$. Active females $(\mathrm{n}=64)$ showed a seroprevalence of $4.7 \%$, while there were not positive inactive females $(n=65)$, but we did not test for statistical differences because of the low sample size of positive females. Larger $A$. azarae (weight class III) showed a higher frequency of antibodies $(40.6 \%, \mathrm{n}=32)$, than the other classes ( $\mathrm{I}$ and II, $\chi^{2}=20.63, \mathrm{df}=2, \mathrm{P}<.001$ ).

We did not detect hantavirus antibodies in none of the seven Calomys analyzed.

Seroprevalence variations according to the sampling period - The few captures of $O$. flavescens in each sampling period prevented us to analyze differences in the proportion of positive animals among them. 
TABLE

Hantavirus antibody seroprevalence and rodent abundance variations according to the sampling period

\begin{tabular}{|c|c|c|c|c|c|c|c|c|}
\hline & & \multicolumn{3}{|c|}{ Captured (Not recaptured) } & \multicolumn{3}{|c|}{ Positive ELISA test } & \multirow{2}{*}{$\begin{array}{c}\text { Positive } \\
\text { PCR }\end{array}$} \\
\hline & & Male & Female & Total & Male & Female & Total & \\
\hline March 1999 & $\begin{array}{l}\text { Akodon azarae } \\
\text { Oligoryzomys flavescens } \\
\text { Calomys sp. }\end{array}$ & $\begin{array}{r}20 \\
4 \\
1\end{array}$ & $\begin{array}{r}17 \\
4 \\
3\end{array}$ & $\begin{array}{r}37 \\
8 \\
4\end{array}$ & $\begin{array}{l}5 \\
0 \\
0\end{array}$ & $\begin{array}{l}2 \\
0 \\
0\end{array}$ & $\begin{array}{l}7 \\
0 \\
0\end{array}$ & $\begin{array}{l}6 \\
- \\
-\end{array}$ \\
\hline July 1999 & $\begin{array}{l}\text { Akodon azarae } \\
\text { Oligoryzomys flavescens } \\
\text { Calomys sp. }\end{array}$ & $\begin{array}{r}29 \\
7 \\
0\end{array}$ & $\begin{array}{r}21 \\
7 \\
0\end{array}$ & $\begin{array}{r}50 \\
14 \\
0\end{array}$ & $\begin{array}{l}6 \\
0 \\
-\end{array}$ & $\begin{array}{l}0 \\
1 \\
-\end{array}$ & $\begin{array}{l}6 \\
1 \\
-\end{array}$ & $\begin{array}{l}5 \\
1 \\
-\end{array}$ \\
\hline September 2000 & $\begin{array}{l}\text { Akodon azarae } \\
\text { Oligoryzomys flavescens } \\
\text { Calomys sp. }\end{array}$ & $\begin{array}{r}25 \\
7 \\
1\end{array}$ & $\begin{array}{r}19 \\
6 \\
1\end{array}$ & $\begin{array}{r}44 \\
13 \\
2\end{array}$ & $\begin{array}{l}6 \\
1 \\
0\end{array}$ & $\begin{array}{l}0 \\
2 \\
0\end{array}$ & $\begin{array}{l}6 \\
3 \\
0\end{array}$ & $\begin{array}{l}1 \\
2^{a} \\
-\end{array}$ \\
\hline December 2000 & $\begin{array}{l}\text { Akodon azarae } \\
\text { Oligoryzomys flavescens } \\
\text { Calomys sp. }\end{array}$ & $\begin{array}{r}37 \\
1 \\
0\end{array}$ & $\begin{array}{r}31 \\
0 \\
0\end{array}$ & $\begin{array}{r}68 \\
1 \\
0\end{array}$ & $\begin{array}{l}5 \\
1 \\
-\end{array}$ & $\begin{array}{l}1 \\
- \\
-\end{array}$ & $\begin{array}{l}6 \\
1 \\
-\end{array}$ & $\begin{array}{l}- \\
1 \\
-\end{array}$ \\
\hline March 2001 & $\begin{array}{l}\text { Akodon azarae } \\
\text { Oligoryzomys flavescens } \\
\text { Calomys sp. }\end{array}$ & $\begin{array}{r}47 \\
1 \\
0\end{array}$ & $\begin{array}{r}45 \\
0 \\
1\end{array}$ & $\begin{array}{r}92 \\
1 \\
1\end{array}$ & $\begin{array}{l}2 \\
0 \\
-\end{array}$ & $\begin{array}{l}0 \\
- \\
0\end{array}$ & $\begin{array}{l}2 \\
0 \\
0\end{array}$ & $\begin{array}{l}- \\
- \\
-\end{array}$ \\
\hline Totals/ species & $\begin{array}{l}\text { Akodon azarae } \\
\text { Oligoryzomys flavescens } \\
\text { Calomys sp. }\end{array}$ & $\begin{array}{r}158 \\
20 \\
2\end{array}$ & $\begin{array}{r}133 \\
17 \\
5\end{array}$ & $\begin{array}{r}291 \\
37 \\
7\end{array}$ & $\begin{array}{r}24 \\
2 \\
0\end{array}$ & $\begin{array}{l}3 \\
3 \\
0\end{array}$ & $\begin{array}{r}27 \\
5 \\
0\end{array}$ & $\begin{array}{c}12 \\
4^{a}\end{array}$ \\
\hline
\end{tabular}

$a$ : in September 2000 the polymerase chain reaction (PCR) was not conducted in one ELISA positive $O$. flavescens which was not removed.

Antibody seroprevalence in $A$. azarae was differentially distributed among samplings $\left(\chi^{2}=9.44, \mathrm{df}=4\right.$, $\mathrm{P}=0.05)$ with a minimum in March $2001(3.1 \%, \mathrm{n}=87)$, when population density was high, and a maximum in March $1999(18.9 \%, \mathrm{n}=37)$, when there was low density (Table).

Seroconversion rates of recapture animals - From six A. azarae recaptured only one time each (four males and two females), two males become positive during the three months period elapsed between captures (one between September and December 2000, and the other between December 2000 and March 2001), while the other two maintained their condition (one remained positive between September and December 2000 and the other negative between December 2000 and March 2001). Both females remained negative in both captures.

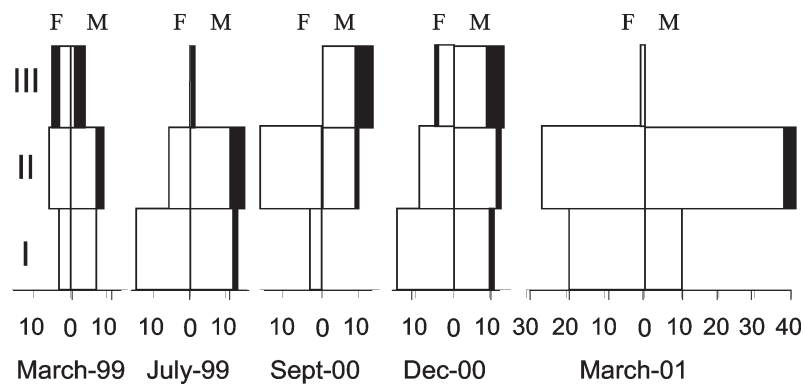

Fig. 2: distribution of mass classes (I, II, III) and seroprevalence in the Akodon azarae population in the different periods. In black: positive animals; F: female; $\mathrm{M}$ : male
Confirmation of presence of hantavirus genomic material and characterization of viral genotypes - In order to estimate hantavirus prevalence within the antibody positive population, total RNA extraction and partial viral genome amplification of the coding region from the $\mathrm{S}$ segment were performed when tissue samples were available. Molecular analyses was positive for the 4 ELISA positive of $O$. flavescens, and for 12 out of $14 \mathrm{~A}$. azarae (Table). We preferred to study $O$. flavescens due to two reasons, one of them was the cost of the molecular analyses, and the other one was the previous result which confirmed the Pergamino genotype in $A$. azarae (Levis et al. 1998). Two additional antibody non reactive $O$. flavescens were positive for viral detection.

In order to characterize virus genotypes, four randomly selected amplimers from positive A. azarae and four amplimers from $O$. flavescens were sequenced and analyzed for comparison with corresponding sequences of representative hantavirus. Pergamino virus was characterized from four seropositive $A$. azarae and one negative $O$. flavescens. The four viruses from the $A$. azarae had the same sequence in the $\mathrm{N}$ conserved fragment. Pergamino virus from the $O$. flavescens differed in one out of 274 nucleotides in this fragment. AND Cent Lec was identified in two antibody positive and one antibody negative $O$. flavescens. None of the virus lineages circulating in central Argentina region studied previously (Padula et al. 2000a) differed from each other by more than $5 \%$ in the $\mathrm{N}$ conserved fragment. For this reason another fragment coding for the glycoprotein G2 from the M segment was sequenced in the three $O$. flavescens viruses. Sequence identity differences up to $17.2 \%$ and up to $2.7 \%$ 
were seen in nucleotidic and aminoacidic levels, respectively, when the three G2 fragment sequences were compared.

\section{DISCUSSION}

Our results confirm $O$. flavescens as the reservoir of the AND Cent Lec virus, responsible of many HPS cases in central Argentina, and show that the virus is more extended in rodent populations than expected according to human cases. The identification of the Pergamino virus in A. azarae also agrees with previous studies (Calderón et al. 1999, Padula et al. 2000a). The detection of Pergamino virus in one individual of $O$. flavescens suggests that the virus was transmitted between $A$. azarae and $O$. flavescens, but it could had been an incidental infection which not resulted in persistent infection. However, this result also reveals that two different lineages of hantaviruses can be cocirculating in the same species at the same location.

The rates of hantavirus seroprevalence found in $A$. azarae and $O$. flavescens in this study were almost three times higher than those recorded by Calderón et al. (1999) in localities of Buenos Aires province where cases of HPS have been reported: $9.3, \mathrm{n}=291$ versus $2.7 \%, \mathrm{n}=549 \mathrm{P}<$ 0.0001 for A. azarae and $13.5, \mathrm{n}=37$ versus $4.7 \%, \mathrm{n}=170$ $\mathrm{P}<0.05$ for $O$. flavescens, for this study and Calderón's study, respectively, test of comparison of two percentages (Bailey 1981). Strong variations in seroprevalences are not only evident when comparing studies conducted by different authors, but also within habitats and times (Abbott et al. 1999, Mills et al. 1999). In Argentina and other areas of the Americas seroprevalence range between 3-14\% (Calderón et al. 1999, Cantoni et al. 2001, Yahnke et al. 2001). However, the difference in seroprevalence could also be attributed to the different type of antigen used to estimate seroprevalence in each study (Sin Nombre and AND antigens for Calderón et al.'s and our study, respectively), although Toro et al. (1998) did not find differences in serologic results obtained with these two types of antigen.

The higher rates of hantavirus seroprevalence found in larger and reproductively active (i.e., older) individuals of $A$. azarae, and specially in males, is in agreement with that observed in O. longicaudatus in Southern Argentina by Cantoni et al. (2001), in C. laucha in Paraguay by Yahnke et al. (2001) in species of Peromyscus in the United States (Abbott et al. 1999, Kuenzi et al. 1999, Mills et al. 1999), and in C. musculinus infected with Junín virus (Mills et al. 1994). Differences in seroprevalence among age classes and sexes have been related to horizontal transmission that involves a higher chance of older individuals of being infected, since they have a longer period of exposition to the virus (i.e., the "age factor"). On the other hand, the higher prevalence of antibodies in $A$. azarae active males is probably related to their large range of movements (Cittadino et al. 1998) which increase the probability of virus transmission. The few evidences of aggressions found in our study suggest that fighting and biting would not be a common mechanism of virus transmission among $A$. azarae males, in contrast with that observed for Peromyscus (Mills \& Childs 1998).
The absence of differences in seroprevalence between sexes, and the social behavior of $O$. flavescens (Crespo 1966), suggest that viral transmission in this species may occurred during communal nesting in winter, as was observed for deer mice populations (Mills et al. 1999). However, Cantoni et al. (2001) observed a higher prevalence of antibodies in $O$. longicaudatus adult males than in juveniles and females, although this species also shows communal nesting. We captured few $O$. flavescens, and most of them in the winter period, so more extensive studies on this species are needed to have conclusive information about the pattern of seroprevalence variation within its populations.

The low seroprevalence observed in the A. azarae population in March 2001 may have been caused by a dilution of the few adults present (with high seroprevalence) within a dense population with a high proportion of juveniles (which were not infected). In March 1999 , by the contrary, the population was mainly composed by adult individuals which contributed to the high seroprevalence observed.

The presence of AND Cent Lec viral lineage in the rodent populations of the area suggests that the human population is at risk of HPS disease. At present, there are no reported cases of this disease in the studied department of Exaltación de la Cruz, although there were reported cases of HPS in the neighbor departments of Zárate, Campana, Pilar and Escobar (Fig. 1). The lower human population density in Exaltación de la Cruz (25.8 inhabitants $/ \mathrm{km}^{2}$ ) with respect to Campana, Zárate, Pilar and Escobar (72.8, 76.2, 369.9 and 463.6, respectively; INDEC 1991) may cause a lower probability of detection of HPS cases because of a lower probability of encounter between infected rodents and humans. Nevertheless, the infection risk in Exaltación de la Cruz may be high for special demographic groups, which live or work in rural areas where rodent densities are high.

According to our results, we consider that the sanitary authorities of the area should pay special attention to the risk of cases of HPS, specially if there are changes in the land use, as was observed for Argentine hemorrhagic fever, where the etiologic agent (Junín virus) was detected in rodents years before the first human cases of the disease were reported (Parodi et al. 1961, Weissenbacher et al. 1985, Kravetz et al. 1986).

The high prevalence of Pergamino virus in A. azarae populations, a species widely distributed in rural and peridomestic habits of central Argentina, also represents a potential risk because we can not discard that this virus can become patogenic for humans.

\section{REFERENCES}

Abbott KD, Ksiazek TG, Mills JN 1999. Long-term hantavirus persistence in rodent populations in Central Arizona. Emerg Infect Dis 5: 102-112.

Bailey NTJ 1981. Statistical Methods in Biology, 2nd. ed., Hodder and Stoughton, London.

Biggs JR, Bennett KD, Mullen MA, Haarmann TK, Salisbury SM, Robinson RJ, Keller D, Torrez-Martinez N, Hjelle B 2000. Relationship of ecological variables to Sin Nombre Virus antibody seroprevalence in populations of deer mice. J Mammal 81: 676-682.

Busch M, Kravetz FO 1992. Competitive interactions among 
rodents (Akodon azarae, Calomys laucha, C. musculinus and Oligoryzomys flavescens) in a two-habitat system. I. Spatial and numerical relationships. Mammalia 56: 45-56.

Calderón G, Pini N, Bolpe J, Levis S, Mills JN, Segura E, Guthmann N, Cantoni G, Becker J, Fonollat A, Rijpoll C, Bortman M, Benedetti R, Sabattini M, Enria KD 1999. Hantavirus reservoir hosts associated with peridomestic habitats in Argentina. Emerg Infect Dis 5: 792-797.

Cantoni G, Padula P, Calderón G, Mills JN, Herrero E, Sandoval P, Martínez V, Pini N, Larrieu E 2001. Seasonal variations in prevalence of antibody to hantaviruses in rodents from southern Argentina. Trop Med Int Health 6: 811-816.

Cittadino EA, Busch M, Kravetz FO 1998. Population abundance and dispersal in Akodon azarae (Pampean grassland mouse) in Argentina. Can J Zool 76: 1011-1018.

Crespo JA 1966. Ecología de una comunidad de roedores silvestres en el Partido de Rojas, Provincia de Buenos Aires. Rev Mus Argent Ci Nat Bernardino Rivadavia 1: 79-134.

Gonzalez della Valle M, Edelstein A, Miguel S, Martinez V, Cortez J, Cacace ML, Jurgelenas G, Sosa Estani S, Padula P 2002. Andes virus associated with HPS in Northern Argentina and determination of the precise site of infection. Am J Trop Med Hyg 66: 713-720.

Graham TB, Chomel BB 1997. Population dynamics of the Deer Mouse (Peromyscus maniculatus) and Sin Nombre Virus, California Channel Islands. Emerg Infect Dis 3: 367370.

INDEC-Instituto Nacional de Estadísticas y Censos 1991. Censo Nacional de Población y Vivienda, Secretaría de Planificación, Presidencia de la Nación, República Argentina.

Kravetz FO, Percich RE, Zuleta GA, Calello MA, Weissenbacher MC 1986. Distribution of Junín virus and its reservoris. A tool for Argentine hemorrhagic fever risk evaluation in non-endemic areas. Interciencia 11: 185-188.

Kuenzi AJ, Morrison ML, Swann DE, Hardy PC, Downard GT 1999. A long study of Sin Nombre virus prevalence in rodents, southeastern Arizona. Emerg Infect Dis 5: 113117.

Levis S, Morzunov SP, Rowe JE, Enria D, Pini N, Calderon G, Sabattini M, St Jeor SC 1998. Genetic diversity and epidemiology of hantaviruses in Argentina. J Infect Dis 177: 529-538.

López N, Padula P, Rossi C, Lazaro ME, Franze-Fernandez MT 1996. Genetic identification of a new hantavirus causing severe pulmonary syndrome in Argentina. Virology 220: 223-226.

López N, Padula P, Rossi C, Miguel S, Edelstein A, Ramírez E, Franze-Fernandez MT 1997. Genetic characterization and phylogeny of Andes virus and variants from Argentina and Chile. Virus Res 50: 77-84.

Martínez VP, Colavecchia S, García Alay M, Suzuki B, Tricheri A, Busto S, Ravinovich R, Padula P 2001. Síndrome pulmonar por hantavirus en la Provincia de Buenos Aires. Medicina 61: 147-156.

Mills JN, Childs JE 1998. Ecologic studies of rodent reservoirs: their relevance for human health. Emerg Infect Dis 4: 529538.

Mills JN, Childs JE, Ksiazek TG, Peters MD, Velleca WM 1995. Methods for Trapping and Sampling Small Mammals for Virologic Testing, US Department of Health and Human Services, Public Health Service, Centers for Disease Control and Prevention, Atlanta, $61 \mathrm{pp}$.

Mills JN, Ellis BA, Childs JE, Ksiazek TG, Jahrling PB 1994. Prevalence of infection with Junín virus in rodent populations in the epidemic area of Argentine hemorrhagic fever. Am J Trop Med Hyg 5: 554-562.

Mills JN, Ellis BA, McKee KT, Maiztegui JI, Childs JE 1991. Habitat associations and relative densities of rodent populations in cultivated areas of central Argentina. $J$ Mammal 72: 470-479.

Mills JN, Ksiazek TG, Peters CJ, Childs JE 1999. Long-term studies of hantavirus reservoir populations in the Southwestern United States: a synthesis. Emerg Infect Dis 5: $142-152$.

Nichol ST, Spiropoulou CF, Morzunov S, Rollin PE, Ksiazek TG, Feldmann H, Sanchez A, Childs J, Zaki S, Peters CJ 1993. Genetic identification of a hantavirus associated with an outbreak of acute respiratory illness. Science 262: 914917.

Padula P, González Della Valle M, García Alai M, Cortada P, Villagra M, Gianella A 2002. Andes virus and first case report of Bermejo virus causing fatal pulmonary syndrome. Emerg Infect Dis 8: 437-439.

Padula PJ, Colavecchia SB, Martinez VP, Gonzalez Della Valle MO, Edelstein A, Miguel SD, Russi J, Riquelme JM, Colucci N, Almiron M, Rabinovich RD 2000a. Genetic diversity, distribution, and serological features of hantavirus infection in five countries in South America. J Clin Microbiol 38: 3029-3035.

Padula PJ, Rossi C, Della Valle MO, Martínez PV, Colaveccchia SB, Edelstein A, Miguel S, Rabinovich R, Segura E 2000b. Development and evaluation of a solid phase enzyme immunoassay based on Andes virus recombinant nucleoprotein. J Med Microbiol 49: 149-155.

PAHO-Pan American Health Organization 2002. 2nd Joint Meeting of the Surveillance Network for Emerging Diseases in the Amazon and Southern Cone Regions. 23-24 March, Atlanta, Georgia, US. [on line]. 134 pp. <http://www. paho.org/English/HCP/HCT/EER/redes-eer-atl-2002.htm>

Parodi AS, Ruggiero M, Greenway DJ, Mettler NE, Boxaca MC 1961. Aisalmiento del virus Junín de roedores de zonas no epidémicas. Prensa Méd Argentina 46: 554-559.

Romano-Lieber NS, Yee J, Hjelle B 2001. Serologic survey for hantavirus infections among wild animals in rural areas of São Paulo State, Brazil. Rev Inst Med Trop São Paulo 43: 325- 327.

Sosa Estani S, Martínez PV, Gonzalez della Valle M, Edelstein A, Miguel S, Padula PJ, Cacase ML, Segura SL 2002. Hantavirus in human and rodent population in an endemic area of hantavirus pulmonary syndrome in Argentina. Medicina 62: 1-8.

Toro J, Vega JD, Khan AS, Mills JN, Padula P, Terry W, Yadón Z, Valderrama R, Ellis BA, Pavletic C, Cerda R, KZaki S, Wun-Ju S, Meyer RS, Tapia M, Mansilla C, Baro M, Vergara JA, Concha M, Calderón G, Enria KD, Peters CJ, Ksiazek TG 1998. An outbreak of hantavirus pulmonary syndrome, Chile, 1997. Emerg Infect Dis 4: 687-694.

Vasconcelos PFC, Mills JN, Rosa EST 2001. An ecologic study of reservoir rodents following three cases of Hantavirus Pulmonary Syndrome in Anajatuba, Maranhão State, Brasil. Abstracts of The Fifth International Conference on Hemorrhaghic Fever with Renal Syndrome (HFRS), Hantavirus Pulmonary Syndrome (HPS), and hantaviruses, 13-16 June, p. 49.

Yahnke CJ, Meserve PL, Ksiazek TG, Mills JN 2001. Patterns of infection with Laguna Negra virus in wild populations of Calomys laucha in the central Paraguayan Chaco. Am J Trop Med Hyg 26: 768-776.

Weissenbacher MC, Calello MA, Carballal G, Planes N, de la Vega MT, Kravetz FO 1985. Actividad del virus Junín en humanos y roedores de áreas no endémicas de la provincia de Buenos Aires. Medicina 45: 263-268.

Zuleta GA, Kravetz FO, Busch M, Percich RE 1988. Dinámica poblacional del ratón del pastizal pampeano (Akodon azarae) en ecosistemas agrarios de Argentina. Rev Chilena Hist Nat 61: 231-244. 